\title{
Analysis of Stunting among Toddlers at Mauk Health Centre Tangerang Regency
}

\author{
Bunga Tiara Carolin ${ }^{1 *}$, Jenny Anna Siauta², Nur Amamah ${ }^{3}$, Shinta Novelia ${ }^{4}$ \\ 1,2,3,4Midwifery Study Program, Faculty of Health Sciences, Nasional University; \\ bunga.tiara@civitas.unas.ac.ld (Corresponding Author)
}

\section{Article Info: \\ Submitted: \\ 20-08-2021 \\ Revised: \\ 26-09-2021 \\ Accepted: \\ 02-10-2021}

DOI:

https://doi.org/10.53713/nhs.v1i2.56

\section{(c) (1) (2)}

This work is licensed

under CC BY-SA License.

\begin{abstract}
Stunting is one of the problems that hinders human development globally. In Indonesia, the incidence of stunting is around $30.8 \%$, Banten Province $36.9 \%$ and in Tangerang Regency $38 \%$ where this is still far from the target set by WHO, which is $20 \%$. The objective of this study is to identify the analysis of stunting among toddler in Mauk Public Health Center Tangerang District. This was an analytical survey with a case control design. The sample of this study was 132 people consisting of 66 cases and 66 control groups. Quota sampling sampling technique. The research instrument used a questionnaire. Data analysis used chi-square test. The results show that majority of respondents who did not experience stunting was $84.2 \%$, good knowledge of the mother was $55.3 \%$, the mother's height was not short $64.4 \%$, not given exclusive breastfeeding was $51.5 \%$, did not experience LBW was $72.7 \%$, the small number of family members was $57.6 \%$, and a low family income was $64.4 \%$. The results of the bivariate analysis obtained knowledge $(p=0.000)$, history of exclusive breastfeeding ( $p$ $=0.000)$, number of family members $(p=0.000)$, family income $(p=0.029)$, and history of LBW ( $p=0.079)$. The variable most associated with stunting in children under five mong toddlers was maternal height $(O R=6.00)$. Therefore, it is hoped that health workers will improve the $\mathrm{MCH}$, Family Planning and Nutrition programs to be better in the future, with more emphasis on the stunting locus program (special stunting locations), by increasing the fulfillment of balanced nutrition during the first 1000 days of life.
\end{abstract}

Keywords: stunting; toddler; public health center

\section{INTRODUCTION}

Stunting is one of the problems that hinder human development globally. Currently, there are around 162 million toddlers experiencing stunting. If this trend continues, it is projected that by 2025, 127 million toddlers will experience stunting (WHO, 2013). According to the United Nations Children's Emergency Fund (UNICEF), more than half of stunted children or $56 \%$ live in ASIA and more than a third or 37\% live in Africa (UNICEF, 2016). Stunting in children is a serious problem, because it is associated with a greater risk of morbidity and mortality, obesity and non-communicable diseases in the future, short adults, poor cognitive development, and lower productivity and income. Every year about 10.5 million child deaths are related to malnutrition. Where $98 \%$ of these deaths are reported in developing countries (UNICEF, 2013).

Indonesia is still experiencing problems in terms of nutrition and child development. UNICEF stated that around $80 \%$ of stunted children are found in 24 developing countries in Asia and Africa. Indonesia is the fifth country with the highest prevalence of stunting after India, China, Nigeria and Pakistan. Currently, the prevalence of stunting among toddlers in South Asia was around 38\% (UNICEF, 2013).

The results of the Basic Health Research noted that the prevalence of stunting in 2013 was $35.6 \%$, increased in 2015 to $37.5 \%$ and decreased in 2018 to $30.8 \%$. From this prevalence, it can be seen that the prevalence of stunting in Indonesia has decreased significantly even though the figure is still said to be large because it is still above the target set by the WHO, which was $20 \%$. Therefore, the percentage of stunted children in Indonesia was still high and is a health problem that must be addressed (Kemenkes RI, 2018). Banten Province is still facing challenges in terms of nutrition (stunting). The prevalence of stunting in Banten Province in 2018 was $36.9 \%$. The number of edits in Tangerang Regency in 2018 showed a high number, ranging from 38\%. This figure is higher than the prevalence of stunting in Banten, which is of course a problem for the Tangerang Regency government to immediately address this problem (Tangerang District Health Office, 2019). 
Factors related to stunting consist of basic factors such as economic factors, mother's education and mother's knowledge, then intermediate factors such as number of family members, mother's height, mother's age, and number of mother's children. Next are proximal factors such as exclusive breastfeeding, child age and low birth weight (Darteh et al, 2014). The bad impact that can be caused by nutritional problems (stunting), in the short term is disruption of brain development and intelligence, impaired physical growth, and metabolic disorders in the body. In the long term, the bad consequences that can be caused are decreased cognitive abilities and learning achievement, decreased immunity so that they are easy to get sick, and a high risk for the emergence of diabetes, obesity, heart and blood vessel disease, cancer, stroke, and disability in old age, as well as uncompetitive work quality which results in low economic productivity (Kemenkes Rl, 2016).

Research conducted by Ni'mah and Nadhiroh (2016) on toddlers in the working area of the Tanah Kali Kewall Health Center, Surabaya City found the results that basic factors were factors that greatly influenced the incidence of stunting. This is proven by the results of statistical tests carried out found that there was a significant relationship between family income, mother's education, and mother's knowledge with the incidence of stunting in toddlers.

Mauk Public Health Center, Tangerang Regency, is one of the health centers in Tangerang Regency. The incidence of stunting at the Mauk Health Center in Tangerang Regency in 2017 was 778 toddlers (10.4\%) of the 7450 toddlers recorded, this number increased in 2018 to 801 toddlers (10.7\%) from 7510 toddlers and in 2019, 790 toddlers (10.5\%) out of 7531 toddlers. Meanwhile, for the period from January to March 2020, data from the Mauk Health Center, Tangerang Regency, the results of weighing operations or weighing months for toddlers at the Mauk Health Center, it was recorded that from 4424 toddlers at the Mauk Health Center who were weighed and measured their height, the incidence of stunting in toddlers was 788 toddlers $(17,8 \%)$, this figure is certainly a significant increase from the previous years. Based on this incident, the researchers were interested in conducting a study entitled Analysis of Stunting Incidences in Toddlers at the Mauk Public Health Center, Tangerang Regency.

\section{METHOD}

The research design is an analytical survey case control study. The population in this study were all mothers who had toddlers at the Mauk Public Health Center, Tangerang Regency for the period March - May 2020, which consisted of 417 people with the number of stunting cases in toddlers 66 . Sampling technique used quota sampling. So the sample in the case group was 66 people and the control group was 66 people, so the total number of samples from this study was 132 people. The dependent variable is the incidence of stunting in toddlers while the independent variables are mother's knowledge, height, history of exclusive breastfeeding, history of LBW, number of family members, and family income. The research instrument used was a questionnaire. Data analysis consisted of univariate and bivariate analysis. Bivariate analysis using Chi Square test. 


\section{RESULT}

Table 1. Variable of stunting in toddlers $(n=66)$

\begin{tabular}{lll}
\hline \multicolumn{1}{c}{ Variable } & $\mathbf{n}$ & $\%$ \\
\hline $\begin{array}{l}\text { Incidence of stunting } \\
\text { Yes }\end{array}$ & 66 & 50 \\
No & 66 & 50 \\
\hline Maternal Knowledge & & \\
$\quad$ No good & 59 & 44.7 \\
$\quad$ Good & 73 & 55.3 \\
\hline Height & & \\
Short & 47 & 35.6 \\
$\quad$ Not short & 85 & 64.4 \\
\hline Exclusive breastfeeding history & & \\
$\quad$ No & 68 & 51.5 \\
Yes & 64 & 48.5 \\
\hline LBW history & & \\
Yes & 36 & 27.3 \\
$\quad$ No & 96 & 72.7 \\
\hline Number of family members & & \\
Big & 56 & 42.4 \\
Small & 76 & 57.6 \\
\hline Family income & & \\
Low & 85 & 64.4 \\
High & 47 & 35.6 \\
\hline
\end{tabular}

Table 2. The relationship between knowledge, height, history of exclusive breastfeeding, history of LBW and number of family members with the incidence of stunting

\begin{tabular}{|c|c|c|c|c|c|c|c|c|}
\hline \multirow{3}{*}{ Variable } & \multicolumn{4}{|c|}{ Incidence of stunting } & \multirow{2}{*}{\multicolumn{2}{|c|}{ Total }} & \multirow{3}{*}{$p$-value } & \multirow{3}{*}{ OR } \\
\hline & \multicolumn{2}{|c|}{ Yes } & \multicolumn{2}{|c|}{ No } & & & & \\
\hline & $\mathrm{n}$ & $\%$ & $\mathrm{~N}$ & $\%$ & $\mathrm{n}$ & $\%$ & & \\
\hline \multicolumn{9}{|l|}{ Maternal Knowledge } \\
\hline No good & 41 & 62.1 & 18 & 27.3 & 59 & 44.7 & \multirow{3}{*}{0.000} & \multirow{3}{*}{4.373} \\
\hline good & 25 & 37.9 & 48 & 72.7 & 73 & 55.3 & & \\
\hline Total & 66 & 100 & 66 & 100 & 132 & 100 & & \\
\hline \multicolumn{9}{|l|}{ Maternal Height } \\
\hline Short & 36 & 54.5 & 11 & 16.7 & 47 & 35.6 & \multirow{3}{*}{0.000} & \multirow{3}{*}{6.000} \\
\hline Not Short & 30 & 45.5 & 55 & 83.3 & 85 & 64.4 & & \\
\hline Total & 66 & 100 & 66 & 100 & 132 & 100 & & \\
\hline \multicolumn{9}{|c|}{ Exclusive breastfeeding history } \\
\hline No & 45 & 68.2 & 23 & 34.8 & 68 & 51.5 & \multirow{3}{*}{0.000} & \multirow{3}{*}{4.000} \\
\hline Yes & 21 & 31.8 & 43 & 65.2 & 64 & 48.5 & & \\
\hline Total & 66 & 100 & 66 & 100 & 132 & 100 & & \\
\hline \multicolumn{9}{|l|}{ LBW history } \\
\hline Yes & 23 & 34.8 & 13 & 19.7 & 36 & 27.3 & \multirow{3}{*}{0.079} & \multirow{3}{*}{ - } \\
\hline No & 43 & 65.2 & 53 & 80.3 & 96 & 72.7 & & \\
\hline Total & 66 & 100 & 66 & 100 & 132 & 100 & & \\
\hline \multicolumn{9}{|c|}{ Number of family members } \\
\hline $\mathrm{Big}$ & 70 & 60.6 & 16 & 24.2 & 56 & 42.4 & \multirow{3}{*}{0.000} & \multirow{3}{*}{4.808} \\
\hline Small & 26 & 39.4 & 50 & 75.8 & 76 & 57.6 & & \\
\hline Total & 66 & 100 & 66 & 100 & 132 & 100 & & \\
\hline \multicolumn{9}{|l|}{ Family Income } \\
\hline Low & 36 & 54.5 & 49 & 74.2 & 85 & 64.4 & \multirow{3}{*}{0.029} & \multirow{3}{*}{0.416} \\
\hline High & 30 & 45.5 & 17 & 25.8 & 47 & 35.6 & & \\
\hline Total & 66 & 100 & 66 & 100 & 132 & 100 & & \\
\hline
\end{tabular}




\section{DISCUSSION}

\section{Incidence of stunting}

Based on the results of the study, it is known that the research sample was divided into 2 groups equally; the incidence of stunting in toddlers 66 people (50\%), and those who experience stunting 66 people (50\%). According to Gibson (2015) which states that stunting is a condition of a person's nutritional status based on the z-score of height (TB) for age $(U)$ which is located at <-2 SD. The TB/U index is an anthropometric index that describes the nutritional status in the past and is related to environmental and socio-economic conditions. The Decree of the Minister of Health states that short and very short are nutritional status based on the index of Body Length for Age (PB/U) or Height for Age $(T B / U)$ which is the equivalent of the terms stunting (short) and severe stunting (very short). The effect of nutritional deficiency on height can be seen in a relatively long time.

The measurement of stunting in toddlers is measured through a Z-score assessment based on height (TB), weight (BB) and age. This is in accordance with the Decree of the Minister of Health Number 1995/MENKES/SK/XII/2010 concerning Anthropometric Standards for Assessment of Child Nutritional Status, the definition of short and very short is nutritional status based on the Body Length index according to Age (PB/U) or Height. according to Age (TB/U) which is the equivalent of the terms stunting (short) and severe stunting (very short). Short toddlers (stunting) can be detected when a toddler has been measured in length or height, then compared with the standard, and the results are below normal. Short toddlers are toddlers with nutritional status based on length or height according to age when compared to the 2005 WHOMGRS (Multicentre Growth Reference Study) standard, the zscore value is less than -2SD and categorized as very short if the z-score is less than -3SD. The results of this study are in accordance with research conducted by Ni'mah and Nadhiroh (2016) on toddlers in the working area of the Tanah Kali Kewall Health Center, Surabaya City, showing that of the 68 samples, they were divided into 2 equal groups; 34 people $(50 \%)$ who experienced stunting and 34 people $(50 \%)$ who did not experience stunting.

\section{The relationship between knowledge and the incidence of stunting}

Based on the bivariate analysis in this study, it was found that there was a significant relationship between knowledge and the incidence of stunting in toddlers ( $p$-value 0.000 ). Thus, if mothers have less knowledge about nutrition, they are more at risk of having toddlers with stunting than those with good knowledge. The results of this study are in accordance with the opinion expressed by Makhfudli (2014) which states that knowledge is a very important factor in shaping the behavior of each individual, including the individual's health behavior. Behavior that is based on knowledge will last longer than behavior that is not based on knowledge. Likewise, the statement by Kusumawati et al., (2015) was carried out on children under three years of age at the Kedungbanteng Health Center, Banyumas Regency. The results show that there is a significant relationship between mother's knowledge and the incidence of stunting in children under three years of age.

According to the researcher, there is a relationship between knowledge and the incidence of stunting in toddlers because knowledge is the dominant factor in shaping a person's behavior. The better a person's knowledge, the better that person's behavior will be. In this case, it is a mother, the better the mother's knowledge about the health of her toddler and about the nutrition of her toddler, the better the behavior of the mother and the better the health and development of the toddler.

\section{The relationship between maternal height and the incidence of stunting}

Based on the bivariate analysis in this study, it was found that there was a significant relationship between maternal height and the incidence of stunting in toddlers ( $p$-value 0.000 ). Thus, if the mother has a short height, she is more at risk of having a toddler with stunting compared to those whose height is not short.

The results of this study are in accordance with the opinion expressed by Jesmin et al., (2011) which states that stunting in toddlerhood will have a bad impact on the next life that is difficult to repair. Physical growth is related to genetic and environmental factors. Genetic factors include parental height and gender. The short height of the father and mother is a risk of stunting. The prevalence of stunting among toddlers in Indonesia from the group of short mothers $(<150 \mathrm{~cm})$ was $46.7 \%$, while the prevalence of stunting under-fives from the high mother group $(\geq 150 \mathrm{~cm})$ was $34.8 \%$. This is related to the width of the birth canal. In addition, the mother's height and the length of her baby's birth are interrelated. This is due to genetic factors. The results of this study are also in accordance with research conducted by Larasati (2018) on toddlers aged 25-59 months at the Posyandu at the Wonosari II Health Center, where it was found that there was a significant relationship between maternal height and the incidence of stunting in toddlers aged 25-59 months. 
According to researchers, there was a relationship between maternal height and the incidence of stunting in toddlers due to gene factors, of course, very influential on the condition of a baby being born. Mothers with stunting will have the potential to give birth to children who will experience stunting. Genetic factors in the mother such as height affect the incidence of stunting in children under five. However, this does not apply if the short nature of the parents is caused by nutritional or pathological problems experienced by the parents. So, it will not affect the child's height.

\section{The Relationship of Exclusive Breastfeeding History with Stunting Incidents}

Based on the bivariate analysis in this study, it was found that there was a significant relationship between the history of exclusive breastfeeding and the incidence of stunting in children under five ( $p$-value 0.000$)$. Thus, if mothers who did not practice exclusive breastfeeding, it will improve the risk of having toddlers with stunting than mothers who practice exclusive breastfeeding.

The results of this study are in accordance with the opinion expressed by Roesli (2017) which states that exclusive breastfeeding is that babies are only given breast milk without additional fluids such as formula milk, oranges, honey, tea water, water, and without additional solid foods such as bananas, papaya, milk porridge, biscuits, rice porridge. The results of this study are also in accordance with the statement of WHO (2013) which states that breastfeeding has many benefits, for example increasing children's immunity to diseases, ear infections, reducing the frequency of diarrhea, chronic constipation and so on. Lack of breastfeeding and early complementary feeding can increase the risk of stunting, especially in early life. The magnitude of the influence of exclusive breastfeeding on the nutritional status of children makes WHO recommends implementing an intervention to increase breastfeeding for the first 6 months as one of the steps to achieve the WHO Global Nutrition Target 2025 regarding the reduction in the number of among toddlers.

Researchers assumed that the low incidence of stunting in toddlers because exclusive breastfeeding is the best food for babies aged 0-6 months. Breast milk contains a lot of nutrients needed by babies, it can even be said that breast milk has complete nutritional content for babies at the age of 0-6 months. Therefore, most of the infants who were given exclusive breastfeeding did not experience stunting, and most of the babies who were not given exclusive breastfeeding experienced stunting.

\section{The Relationship between LBW History and Stunting Incidents}

Based on the bivariate analysis in this study, it was found that there was no relationship between a history of LBW history and the incidence of stunting in children under five (p-value 0.079). The results of this study are in accordance with the opinion expressed by Umboh (2015), saying that birth weight is one indicator of health in newborns. Birth weight is a parameter that is often used to describe fetal growth during pregnancy. Babies with low birth weight will be more susceptible to adverse environmental influences in the future. The results of this study are in accordance with the results of research conducted by Ni'mah and Nadhiroh (2016) on toddlers in the working area of the Tanah Kali Kewall Health Center, Surabaya City, that there was no relationship between the history of LBW and the incidence of stunting in toddlers.

According to the researcher, there is no significant relationship between the history of LBW and the incidence of stunting in toddlers. The high level of mother's knowledge about the health and nutrition of toddlers affects the behavior patterns of mothers in caring for their toddlers. This is what causes even if the baby is born in a low birth weight state, but with good mother knowledge, of course with good knowledge a mother will behave well in terms of care and maintain the health of her toddler.

\section{The Relationship between the Number of Family Members and the Incidence of Stunting}

Based on the bivariate analysis in this study, it was found that there was a significant relationship between the number of family members and the incidence of stunting among toddlers ( $p$-value 0.000 ). Thus, mothers of toddlers who have large family members are more at risk of having toddlers with stunting compared to mothers of toddlers who have small family members.

The results of this study are in accordance with the opinion expressed by Sediaoetomo (2016) which states that small families will more easily meet their food needs. Families that have a large number of family members if the food supply is sufficient may not necessarily prevent nutritional disorders, because with the increase in the number of members in the family, the food for each family member decreases.

The results of this study are in accordance with the results of Yusdarif's research (2018) conducted on toddlers aged 24-59 months in Rangas Village, Banggae District, Majene Regency. The results showed that there was no significant relationship between the number of family members and the incidence of stunting in toddlers aged 24-59 months. 
According to the researcher, there was a significant relationship between the number of family members and the incidence of stunting because the large number of family members living in one house will certainly have an impact on the value of the nutritional adequacy level of family members. Increasing the number of family members will certainly increase the value of the food consumptive needed and will have an impact on nutritional status, especially during the toddler years.

\section{Relationship between family income and stunting}

Based on the bivariate analysis in this study, it was found that there was a significant relationship between family income and the incidence of stunting among toddlers ( $p$-value 0.000). Thus, mothers of toddlers with low family incomes are more at risk of having toddlers with stunting than mothers of toddlers with high family incomes. UNICEF (2013) statement which states that low economic status is considered to have a significant impact on the likelihood of children being thin and short. Families with good economic status will be able to obtain better public services such as education, health services, road access, and others so that it can affect the nutritional status of children. In addition, the purchasing power of the family will increase so that the family's access to food will be better. The results of Larasati's research (2018) on toddlers aged 25-59 months at the Posyandu in the Wonosari II Health Center area. The results showed that there was a significant relationship between socioeconomic status and the incidence of stunting in children aged 25-59 months. The results of this study are also in accordance with research conducted by Ni'mah and Nadhiroh (2016) on toddlers in the working area of the Tanah Kali Kewall Health Center, Surabaya City. The esearcher assumed that the value of family income level is certainly very influential in fulfilling family nutritional adequacy. The higher the family income, the better the level of family nutrition and it will have an impact on the incidence of stunting among toddlers.

\section{CONCLUSION}

It can be concluded the incidence of stunting among toddlers was 5.8\%, good maternal knowledge was $55.3 \%$, short maternal height was $64.4 \%$, not given exclusive breastfeeding was $51.5 \%$, does not experience LBW was $72.7 \%$, small family members was $57.6 \%$ and the low family income was $64.4 \%$. There was a significant relationship between knowledge ( $p$-value 0.000 ), maternal height ( $p$-value 0.000$)$, history of exclusive breastfeeding ( $p$-value 0.000$)$, number of family members ( $p$-value 0.000 ), and family income (p-value 0.029 ) with the incidence of stunting. The greatest OR value occurred in maternal height, which was 6,000. Meanwhile, in the history of LBW there was no relationship ( $p$-value 0.079 ) with the incidence of stunting. It is hoped that health workers will improve $\mathrm{MCH}$, family planning and nutrition programs to be better in the future, with more emphasis on the stunting locus program (special stunting locations), by increasing the fulfillment of balanced nutrition in the first 1000 days of life.

\section{ACKNOWLEDGEMENT}

Researchers would like to thank all parties that have given contribution and support to the implementation of this community service activity, especially for the Rector, LPPM of Universitas Nasional Faculty of Sciences, Universitas Nasional and the Head of Mauk District Health Center.

\section{REFERENCES}

Azriful, A., Bujawati, E., Habibi, H., Aeni, S., \& Yusdarif, Y. (2018). Determinan Kejadian Stunting Pada Balita Usia 24-59 Bulan di Kelurahan Rangas Kecamatan Banggae Kabupaten Majene. Al-sihah: The Public Health Science Journal, 10(2).

Darteh, E. K. M., Acquah, E., \& Kumi-Kyereme, A. (2014). Correlates of stunting among children in Ghana. BMC public health, 14(1), 1-7.

Dinkes Kab. Tangerang. (2019). Profil Kesehatan Kabupaten Tangerang Tahun 2018. Tangerang : Depkes Kab. Tangerang

Gibson. (2015). Principles of Nutritional Assesment 2nd Ed. Oxford University Press: New York

Jesmin, A., Yamamoto, S. S., Malik, A. A., \& Haque, M. A. (2011). Prevalence and determinants of chronic malnutrition among preschool children: a cross-sectional study in Dhaka City, Bangladesh. Journal of health, population, and nutrition, 29(5), 494.

Kemenkes, RI. (2016). Pedoman Kader Seri Kesehatan Anak. Jakarta: Kementerian Kesehatan Republik Indonesia.

Kemenkes, RI. (2018). Buku Kader Posyandu: Dalam Usaha Perbaikan Gizi Keluarga. Jakarta.

Kusumawati, E., Rahardjo, S., \& Sari, H. P. (2015). Model pengendalian faktor risiko stunting pada anak bawah tiga tahun. Kesmas: Jurnal Kesehatan Masyarakat Nasional (National Public Health Journal), 9(3), 249-256.

Larasati, N. N., \& Wahyuningsih, H. P. (2018). Faktor-Faktor Yang Berhubungan Dengan Kejadian Stunting Pada Balita Usia 25-59 Bulan Di Posyandu Wilayah Puskesmas Wonosari II Tahun 2017 (Doctoral dissertation, Poltekkes Kemenkes Yogyakarta). 
Makhfudli. (2014). Keperawatan Kesehatan Komunitas : Teori dan Praktik dalam Keperawatan. Jakarta : Selemba Medika

Efendi, F., \& Makhfudli, M. (2014). Keperawatan Kesehatan Komunitas: teori dan praktik dalam keperawatan.

Ni'mah, K., \& Nadhiroh, S. R. (2015). Faktor yang berhubungan dengan kejadian stunting pada balita. Media Gizi Indonesia, 10(1), 13-19.

Roesli. (2017). Inisiasi Menyusu Dini Plus ASI Eksklusif. Jakarta: Pustaka Bunda.

Sediaoetomo (2016). Imu Gizi untuk Mahasiswa dan Profesi Jilid VI. Jakarta : Dian Rakyat.

Umboh (2015). Berat Lahir Rendah Dan Tekanan Darah Pada Anak. Jakarta: Sagung Seto.

Unicef. (2013). Improving child nutrition: the achievable imperative for global progress. New York: UNICEF, 1-14.

UNICEF, J. (2013). WHO-The World Bank Child Malnutrition Database: Estimates for 2012 and Launch of Interactive Data Dashboards. 